\title{
The Implementation of the Agreement of Water Pipeline Installation Between Regional Water Companies with CV. Tenjo Laut
}

\author{
Intan Nur Indah, Haris Budiman and Bias Lintang Dialog \\ Faculty of Law, Universitas Kuningan, Indonesia \\ E-mail: intannurindah1405@gmail.com
}

\begin{abstract}
How to cite : Intan Nur Indah, Haris Budiman and Bias Lintang Dialog. "The Implementation of the Agreement of Water Pipeline Installation Between Regional Water Companies with CV. Tenjo Laut”. UNIFIKASI : Jurnal Ilmu Hukum. 6(2). 2019. 219-225. DOI : 10.25134/unifikasi.v6i2.2139

Submitted : 29-07-2019

Revised : 29-11-2019

Accepted : 15-12-2019
\end{abstract}

\begin{abstract}
The present study aims to analyze the arrangement and implementation of the agreement of water pipeline installation between Tirta Kamuning Regional Water Company and CV. Tenjo Laut. This descriptiveanalytical study applied an empirical juridical approach. The results showed that the agreement of water pipeline installation between Tirta Kamuning Regional Water Company and CV. Tenjo Laut was based on the legislations, especially Article 64 of Law No. 13 of 2003, Article 65 Paragraph 3 of Law No. 13 of 2003, Presidential Regulation No. 70 of 2012, Article 1320 of the Civil Code, and Article 1338 of the Civil Code. Thus, in general, the implementation of the agreement of water pipeline installation between Tirta Kamuning Regional Water Company and CV. Tenjo Laut is in accordance with the legislations.
\end{abstract}

Keywords: Agreement, Water, Regional Companies.

\section{Implementasi Perjanjian Pemasangan Pipa Air Minum antara Perusahaan Daerah Air Minum dengan CV. Tenjo Laut}

Abstrak : Tujuan penelitian yaitu untuk mengetahui pengaturan dan implementasi perjanjian pemasangan pipa air minum antara Perusahaan Daerah Air Minum Tirta Kamuning dengan CV. Tenjo Laut. Spesifikasi penelitian yang digunakan adalah penelitian bersifat deskriptif-analitis dengan pendekatan yuridis empiris. Hasil penelitian menunjukkan pengaturan perjanjian pemasangan pipa air minum antara Perusahaan Daerah Air Minum Tirta Kamuning dengan CV. Tenjo Laut didasarkan atas peraturan perundang-undangan yang diatur oleh Pasal 64 Undang-Undang Nomor 13 Tahun 2003, Pasal 65 Ayat 3 Undang-Undang Nomor 13 Tahun 2003, Peraturan Presiden Nomor 70 Tahun 2012, Pasal 1320 Kitab Undang-Undang Hukum (KUH) Perdata, dan Pasal 1338 Kitab Undang-Undang Hukum Perdata; dan implementasi perjanjian pemasangan pipa air minum antara Perusahaan Daerah Air Minum Tirta Kamuning dengan CV. Tenjo Laut pada umumnya sudah sesuai dengan ketentuan perundang-undangan.

Kata Kunci: Perjanjian, Air Minum, Perusahaan Daerah.

\section{INTRODUCTION}

Regional Water Company is a regional-owned enterprise (BUMD) engaged in the field of public services which functions as a provider of clean water and is responsible for fulfilling clean water supply for all residents in the regions. Regional Water Company as a provider of clean water is regulated in Government Regulation No. 122 of 2015 concerning Water Supply System (SPAM) which states that SPAM development can be carried out by BUMN or BUMD. Actually, Government Regulation No. 122 of 2015 mentions several clean water providers, namely: State-Owned Enterprises (BUMN), Regional-Owned Enterprises (BUMD), Cooperatives, Private-Owned Enterprises, and community. However, water resources management must pay attention to general principles of good governance so that the management can be carried out professionally ${ }^{1}$.

The participation of cooperatives, private-owned enterprises, and/or community can only be done if BUMN/BUMD cannot increase the quantity and quality of water supply services in its service area.

\footnotetext{
${ }^{1}$ Suwari Akhmaddhian. Asas-Asas dalam Penyelenggaraan Pemerintahan yang Baik untuk Mewujudkan Good Governace. Logika: Journal of Multidisciplinary Studies, ISSN 2085-9970. Vol. 09 Nomor 01 Juni 2018. 30-38
} 
In this case, the government or regional government can build infrastructure and facilities to provide clean water with a note that after the construction, its operation will be run by BUMN or BUMD. This is in accordance with Government Regulation No. 122 of 2015 concerning Water Supply System (SPAM). ${ }^{2}$ Basically, the government, in accordance with its obligations, has provided public services to the community. Yet, the government needs to ensure that the community can use the facilities at a low cost as there are still many people who complain about these public services. In public services, there is a distinction between profit and non-profit sectors which is based on the mission carried out by these public service agencies/institutions. Regional Water Company is a public service institution that is classified as a profit sector. This type of state-owned enterprises can benefit the community as they are profit-oriented, but their objective is still directed at an effort to realize community prosperity. It is in accordance with the mandate of Article 33 Paragraph (3) of the Law of the Republic of Indonesia. ${ }^{3}$

One of the OPD, the Kuningan District Regional Water Company, was given the authority to provide water services for public use. However, the installation of water pipeline often interferes with road users. The damage of the sidewalk due to the work of excavating the pipeline has made the Kuningan District Public Works and Public Housing Department a party that often becomes the scapegoat in the media. As reported in an online media that the broken pipeline of Regional Water Company causes the Kadugede Road collapsed. Approximately 50 meters of the highway connecting Kuningan - Cikijing had cracked due to water from the main pipeline of the Regional Water Company of Darma Reservoir experiencing a leak. Hence, the Kuningan District Water Company expressed its apology because the incident has caused water supply to Kadugede, Kuningan, Luragung and Garawangi areas as well as the traffic flow were disrupted. This issue was completely resolved at $4.00 \mathrm{a.m}^{4}$

Regulation of the Minister of Public Works and Public Housing of the Republic of Indonesia No. 25/PRT/M/2016 concerning the Implementation of Water Supply System to Fulfill Their Own Needs by Business Entities describes that the implementation of Water Supply System (SPAM) by Business Entity includes the principle of SPAM implementation, type of Business Entities, and scope of services. The principle of SPAM implementation by a Business Entity is to fulfill its own needs, namely fulfilling the daily basic water needs, sustainable development, and good governance. Any Business Entity is guided by the principle of SPAM implementation in carrying out SPAM implementation. Meanwhile, the scope of services includes the determination of service area, service coverage, and service form. In this regards, Tirta Kamuning Regional Water Company has signed an agreement to install water pipeline with CV. Tenjo Laut. This partnership aims to provide consumers protection in which business entity will be responsible for providing compensation to consumers consuming polluted clean water 5 .

To find out whether an agreement is valid or invalid, the agreement must be tested through several conditions. There are at least 4 conditions to measure the validity of an agreement as stipulated in Article 1320 of the Civil Code, namely: consent between those who bind themselves, capacity of the respective parties to conclude an obligation, a certain subject matter, and a permitted cause. First, in order to make the agreement is considered valid by law, both parties must have consent to be bound by the agreement. Second, the terms capacity of the respective parties to

2 Rina Kartika Sari, Klausula Imbalan dalam Perjanjian Kerjasama antara Pemerintah dengan Swasta: Studi Kasus Perjanjian Kerjasama antara PERUSAHAAN DAERAH AIR MINUM DKI Jakarta dengan PT. Aetra Air Jakarta, Jurnal Hukum dan Pembangunan Vol. 7 No. 4 (2011), pp. 2.

3 Irfian, Loc.Cit.

$4 \quad$ Suara Kuningan (Portal Berita Kuningan), Pipa Perusahaan Daerah Air Minum Pecah Sebabkan Jalan Kadugede Amblas, Berita Media Online, 2018, Accessed dari website: http://www.suarakuningan.com pada tanggal 22 Maret 2019.

${ }^{5}$ Dewi Kurniawati. Upaya Pdam Dalam Rangka Pemenuhan Kebutuhan Suplay Air Bersih Kepada Pelanggan Dalam Perspektif Hukum Perlindungan Konsumen Di Kota Pontianak. Jurnal Mahasiswa S2 Hukum Untan 
conclude an obligation means that the party involved must be the person who is legally authorized to make the agreement. Thus, if the agreement cannot be fulfilled by the parties, then one of the parties will default ${ }^{6}$. Third, the terms a certain subject matter means that an agreement must be related to certain thing that is clear and justified by law. Last, a permitted cause means that a contract must be made with the intent/reason in accordance with the applicable law. Thus, it is clear that an agreement cannot be made to do things that are in conflict with law and public order. Based on the description, the problems discussed in this study are formulated into the following questions: 1) how is the arrangement of the agreement of water pipeline installation between Tirta Kamuning Regional Water Company and CV. Tenjo Laut? and 2) How is the implementation of the agreement of water pipeline installation between Tirta Kamuning Regional Water Company and CV. Tenjo Laut?

\section{RESEARCH METHODS}

This descriptive-analytical study applied an empirical juridical approach. This study was done in two stages, namely field research and library research. The data were collected through interview and document analysis. The collected data were then analyzed by applying descriptive analysis method.

\section{RESULTS AND DISCUSSION}

\section{The arrangement of the agreement of water pipeline installation between Tirta Kamuning} Regional Water Company and CV. Tenjo Laut

The agreement of water pipeline installation between Tirta Kamuning Regional Water Company and CV. Tenjo Laut is based on the following legislations: Article 1 No. 14 of Law No. 13 of 2003 concerning Manpower states that a work agreement is an agreement made between a worker/laborer and an entrepreneur or an employer that specifies work requirements, rights, and obligations of both sides. Then, Article 1 No. 15 of Law No. 13 of 2003 concerning Manpower states that an employment relation or relationship is a relationship between an entrepreneur and a worker/labourer based on a work/employment agreement which deals with aspects relating to the job that the worker has to do, the worker's wage, and orders and instructions that the worker has to carry out. Based on these provisions, it can be concluded that a work agreement is the one causing an employment relationship to have elements of jobs, wages and orders. Thus, the agreement of water pipeline installation between Tirta Kamuning Regional Water Company and CV. Tenjo Laut must contain elements of jobs, wages and orders.

In Law concerning manpower in Indonesia, the employment contract is regulated in Article 64 and Article 65 of Law No. 13 of 2003. Article 64 of the Manpower Law notes an enterprise may handover part of its work to another enterprise under a written agreement of contract of work or a written agreement for the provision of labour. Further, Article 65 Paragraph (3) of Law No. 13 of 2003 concerning Manpower states that the other enterprise as refferred to under subsection (1) must be a legal entity. Thus, the enterprise accepting the job as regulated in the Manpower Law must be a legal entity. In this case, the second party receiving the work tender had passed the feasibility test in the administration sector, because before announcing the tender winner, each company was first selected by the Regional Water Company. Therefore, Tirta Kamuning Regional Water Company has made an agreement to install a water pipeline with CV. Tenjo Laut through Agreement Package 14 on Procurement Work, Installation of Distribution Pipeline, Reticulation and Accessories of Cikeusik Village, Cidahu Subdistrict No. 602.1/27/PPK-PDAM/XI/2012.

\footnotetext{
6 Raditama Anindya Kreshna, Ulfa Azizah,SH.,M.Kn, Rachmi Sulistyarini,SH.,MH. LEGAL MEMORANDUM ANALISIS YURIDIS PUTUSAN PENGADILAN NEGERI TRENGGALEK NO: 08/Pdt.G/2012/PN.TL. Jurnal Hukum http://hukum.studentjournal.ub.ac.id/index.php/hukum/article/view/899/890
} 
Presidential Regulation No. 70 of 2012 concerning Second Amendment to Presidential Regulation No. 54 of 2010 concerning Procurement of Government Goods/Services states that every project carried out by the central government or regional government must involve a second party. Accordingly, the project of water pipeline installation organized by Tirta Kamuning Regional Water Company must involve a second party, such as CV. Tenjo Laut, in which this partnership is written in a work agreement. According to Article 1313 of the Civil Code, an agreement (a contract) is an act by which one or more persons bind themselves towards two or more other persons, with the intention to create obligations. Thus, the agreement is only binding on those who make the agreement. Further, according to Article 1320 of the Civil Code, the conditions for a valid agreement are consent between those who bind themselves, capacity of the respective parties to conclude an obligation, a certain subject matter, and a permitted cause. In brief, the conditions for a valid agreement include four things, namely consent, capacity, a certain subject matter, and a permitted cause. Thus, the agreement of water pipeline installation between Tirta Kamuning Regional Water Company and CV. Tenjo Laut must fulfill four legal conditions of a valid agreement, namely consent, capacity, a certain subject matter, and a permitted cause.

Further, Article 1338 of the Civil Code states all agreements that are legally based will act as Law to those parties who made them. Thus, the agreement cannot be withdrawn other than by an agreement of the two parties or for reasons determined by law. The agreement was carried out in good faith. Accordingly, the agreement made between Tirta Kamuning Regional Water Company and CV. Tenjo Laut acts as law for the respective parties. Based on the interview conducted with Tirta Kamuning Regional Water Company, it was found that the arrangement of the agreement of water pipeline installation between Tirta Kamuning Regional Water Company and CV. Tenjo Laut is based on the applicable legislations and is based on the Kuningan District Public Works and Public Housing Department. ${ }^{7}$

\section{The Implementation of the Agreement of Water Pipeline Installation between Tirta Kamuning Regional Water Company and CV. Tenjo Laut}

The implementation of the agreement for water pipeline installation between Tirta Kamuning Regional Water Company and CV. Tenjo Laut is associated with legislation regarding manpower in Indonesia, especially in Article 64 and Article 65 of Law No. 13 of 2003. Article 64 of the Manpower Law notes an enterprise may handover part of its work to another enterprise under a written agreement of contract of work or a written agreement for the provision of labour. In this case, Tirta Kamuning Regional Water Company has made an agreement to install a water pipeline with CV. Tenjo Laut through Agreement Package 14 on Procurement Work, Installation of Distribution Pipeline, Reticulation and Accessories of Cikeusik Village, Cidahu Subdistrict No. 602.1/27/PPKPDAM/XI/2012. Further, Article 65 Paragraph (3) of Law No. 13 of 2003 concerning Manpower states that the other enterprise as refferred to under subsection (1) must be a legal entity. Accordingly, an agreement was made for the installation of water pipelines between Tirta Kamuning Regional Water Company and a legal entity, namely CV. Tenjo Laut.

Presidential Regulation No. 70 of 2012 concerning Second Amendment to Presidential Regulation No. 54 of 2010 concerning Procurement of Government Goods/Services states that every project carried out by the central government or regional government must involve a second party. Hence, the implementation of the agreement of water pipeline installation between Tirta Kamuning Regional Water Company and CV. Tenjo Laut is in accordance with Presidential Regulation No. 70 of 2012. The project of water pipeline installation organized by Tirta Kamuning Regional Water

$7 \quad$ Hasil wawancara dengan Yogi Hilmawan, S.T, Fungsional Subdivisi Pengembangan Manajemen dan SIM Perusahaan Daerah Air Minum Tirta Kamuning, Tanggal 08 Juli 2019 Pukul 15.00 WIB. 
Company has involved a second party, namely CV. Tenjo Laut in which the partnership is written in a work agreement. A work agreement is a business activity carried out by an enterprise through fair competition by applying the principles of Good Corporate Governance and the applicable business ethics ${ }^{8}$.

According to Article 1320 of the Civil Code, the conditions for a valid agreement are consent between those who bind themselves, capacity of the respective parties to conclude an obligation, a certain subject matter, and a permitted cause. In brief, the conditions for a valid agreement include four things, namely consent, capacity, a certain subject matter, and a permitted cause. Referring to the conditions of a valid agreement, the agreement between Tirta Kamuning Regional Water Company and CV. Tenjo Laut can be explained as follows':

a. Consent means that there is an agreement from both parties, namely Tirta Kamuning Regional Water Company and CV. Tenjo Laut, to make a work agreement for the installation of water pipeline.

b. Capacity is the ability to perform a legal act in which both parties are enterprises having the authority to make agreements in accordance with the provisions of the Civil Code.

c. A certain subject matter is mentioned in the agreement concerning the type of work which is the installation of water pipeline with the existence of a Package 14 on Procurement Work, Installation of Distribution Pipeline, Reticulation and Accessories of Cikeusik Village, Cidahu Subdistrict No. 602.1/27/PPK-PDAM/XI/2012. Procurement is the supply of water pipelines; installation of distribution pipeline is the installation of pipeline in water distribution line; reticulation is pipeline used to distribute clean water from reservoirs to customers with sizes smaller than $50 \mathrm{~mm}$; and accessories are accessories for water pipeline connections.

d. A permitted cause means that the agreement must not be in conflict with public interest. The agreement between Tirta Kamuning Regional Water Company and CV. Tenjo Laut is stated in an Agreement No. 602.1/27/PPK-PDAM/XI/2012 concerning Procurement Work, Installation of Distribution Pipeline, Reticulation and Accessories of Cikeusik Village, Cidahu Subdistrict. The agreement was made as an effort to increase the capacity of Regional Water Company in fulfilling water needs for customers as well as Kuningan District community. Thus, as this agreement provides benefits for the community and the Regional Government, it can be concluded that this agreement meets the fourth conditions stated in Article 1320 of the Civil Code.

According to Article 1338 of the Civil Code, all agreements that are legally based will act as Law to those parties who made them. Thus, the agreement cannot be withdrawn other than by an agreement of the two parties or for reasons determined by law. The agreement was carried out in good faith. Accordingly, the agreement made between Tirta Kamuning Regional Water Company and CV. Tenjo Laut acts as law for the respective parties. Based on the interview conducted with Tirta Kamuning Regional Water Company, Mr. Yogi Hilmawan, S.T., as a Subdivision Functional of Management Development and SIM, it was found that there is a problem in the implementation of the agreement of water pipeline installation between Tirta Kamuning Regional Water Company and $\mathrm{CV}$. Tenjo Laut in which the specifications of the goods are not in accordance with the agreement so

\footnotetext{
${ }^{8}$ Rifqy Maulana, Jamhir. Konsep Hukum Perizinan Dan Pembangunan. Jurnal Justisia: Jurnal Ilmu Hukum, Perundangundangan dan Pranata Sosial. Vol.3.1.2018.90-115.

${ }^{9}$ Gios Adhyaksa. Penerapan Asas Perlindungan Yang Seimbang Menurut Kuhperdata Dalam Pelaksanaan Perjanjian Kerja Untuk Waktu Tertentu Dihubungkan Dengan Undang-Undang Nomor 13 Tahun 2003 Tentang Ketenagakerjaan. Jurnal Unifikasi, ISSN 2354-5976 Vol. 3 No. 2 Juli 2016.77-87
} 
that it does not protect the image of Tirta Kamuning Regional Water Company. ${ }^{10}$ Therefore, more adequate supervision is needed for the implementation of the installation work.

Friedman's legal system theory states that law must be seen as a system. Every legal system always contains three components, namely components of legal structure, legal substance, and legal culture $^{11}$. A legal system in actual operation is a complex organism in which structure, substance, and culture interact. In relation to this theory, the components of the legal system relating to the implementation of the agreement of water pipeline installation between Tirta Kamuning Regional Water Company and CV. Tenjo Laut are; 1) Tirta Kamuning Regional Water Company as legal structure, 2) the Package 14 on Procurement Work, Installation of Distribution Pipeline, Reticulation and Accessories of Cikeusik Village, Cidahu Subdistrict No. 602.1/27/PPK-PDAM/XI/2012 as legal substance, and 3) internal and external factors affecting both parties, Tirta Kamuning Regional Water Company and CV. Tenjo Laut, as legal culture.

\section{CONCLUSION}

The arrangement of the agreement of water pipeline installation between Tirta Kamuning Regional Water Company and CV. Tenjo Laut is based on several legislations, namely Article 64 of Law No. 13 of 2003 concerning Manpower stating that an enterprise may handover part of its work to another enterprise under a written agreement of contract of work or a written agreement for the provision of labour; Article 65 Paragraph (3) of Law No. 13 of 2003 concerning Manpower stating that the other enterprise receiving the job must be a legal entity; Presidential Regulation No. 70 of 2012 concerning Second Amendment to Presidential Regulation No. 54 of 2010 concerning Procurement of Government Goods/Services stating that every project carried out by the central government or regional government must involve a second party; Article 1320 of the Civil Code stating that the conditions for a valid agreement are consent between those who bind themselves, capacity of the respective parties to conclude an obligation, a certain subject matter, and a permitted cause; and Article 1338 of the Civil Code stating that all agreements that are legally based will act as Law to those parties who made them.

In general, the implementation of the agreement of water pipeline installation between Tirta Kamuning Regional Water Company and CV. Tenjo Laut is in accordance with the provisions of the legislations, namely Article 64 of Law No. 13 of 2003, Article 65 Paragraph 3 of Law No. 13 of 2003, Presidential Regulation No. 70 of 2012, Article 1320 of the Civil Code, and Article 1338 of the Civil Code. The signing of the agreement indicates that both parties have agreed to collaboratively do the job because CV. Tenjo Laut is a legal entity so it can be said that CV. Tenjo Laut is capable to make an agreement. In the agreement, it is clear that there are a certain subject matter and a permitted cause. Thus, the agreement made by Tirta Kamuning Regional Water Company and CV. Tenjo Laut acts as law for both parties.

\section{SUGGESTION}

Tirta Kamuning Regional Water Company needs to carry out regular monitoring so that its obligation to provide the best service to the community can be achieved. The agreement between Tirta Kamuning Regional Water Company and CV. Tenjo Laut, although civil in nature, involves public interests. Therefore, Tirta Kamuning Regional Water Company must be careful in choosing partner to make a work agreement with. In addition, Tirta Kamuning Regional Water Company is expected to provide a complaints section to accomodate public complaints regarding water pipeline

\footnotetext{
${ }^{10}$ Interview with Yogi Hilmawan, S.T, Fungsional Subdivisi Pengembangan Manajemen dan SIM PERUSAHAAN DAERAH AIR MINUM Tirta Kamuning, Tanggal 08 Juli 2019.

${ }^{11}$ Suwari Akhmaddhian, Penegakan Hukum Lingkungan dan Pengaruhnya Terhadap Pertumbuhan Ekonomi di Indonesia (Studi Kebakaran Hutan Tahun 2015), Jurnal Unifikasi, Vol. 03 No. 1 Januari 2016.1-35.
} 
problems. Further, Tirta Kamuning Regional Water Company needs to replace old water pipeline or damaged production facilities because water quality must be prioritized. If there is a cessation/problem of water flow, Tirta Kamuning Regional Water Company should notify the cause to the customer directly, not only via radio, so that the customer can understand the problem being faced and do not give a bad rating on the performance of Regional Water Company.

\section{REFERENCES}

Dewi Kurniawati. Upaya PDAM Dalam Rangka Pemenuhan Kebutuhan Suplay Air Bersih Kepada Pelanggan Dalam Perspektif Hukum Perlindungan Konsumen Di Kota Pontianak. Jurnal Mahasiswa S2 Hukum Untan

Gios Adhyaksa. 2016. Penerapan Asas Perlindungan Yang Seimbang Menurut Kuhperdata Dalam Pelaksanaan Perjanjian Kerja Untuk Waktu Tertentu Dihubungkan Dengan UndangUndang Nomor 13 Tahun 2003 Tentang Ketenagakerjaan. Jurnal Unifikasi, ISSN 23545976 Vol. 3 No. 2 Juli 2016.77-87

Raditama Anindya Kreshna, Ulfa Azizah,SH.,M.Kn, Rachmi Sulistyarini,SH.,MH. LEGAL MEMORANDUM ANALISIS YURIDIS PUTUSAN PENGADILAN NEGERI TRENGGALEK NO: 08/Pdt.G/2012/PN.TL. Jurnal Hukum http://hukum.studentjournal.ub.ac.id/index.php/hukum/article/view/899/890

Rifqy Maulana, Jamhir. 2018. Konsep Hukum Perizinan dan Pembangunan. Jurnal Justisia: Jurnal Ilmu Hukum, Perundang-undangan dan Pranata Sosial. Vol.3.1.2018.90-115

Rina Kartika Sari, 2011. Klausula Imbalan dalam Perjanjian Kerjasama antara Pemerintah dengan Swasta: Studi Kasus Perjanjian Kerjasama antara PDAM DKI Jakarta dengan PT. Aetra Air Jakarta, Jurnal Hukum dan Pembangunan Vol. 7 No. 4 (2011), hlm. 2.

Suara Kuningan (Portal Berita Kuningan), Pipa PDAM Pecah Sebabkan Jalan Kadugede Amblas, Berita Media Online, 2018, diakses dari website: http://www.suarakuningan.com pada tanggal 22 Maret 2019.

Suwari Akhmaddhian, 2016. Penegakan Hukum Lingkungan dan Pengaruhnya Terhadap Pertumbuhan Ekonomi di Indonesia (Studi Kebakaran Hutan Tahun 2015), Jurnal Unifikasi, Vol. 03 No. 1 Januari 2016.1-35.

Suwari Akhmaddhian. 2018. Asas-Asas dalam Penyelenggaraan Pemerintahan yang Baik untuk Mewujudkan Good Governace. Logika : Journal of Multidisciplinary Studies, ISSN 20859970. Vol. 09 Nomor 01 Juni 2018. 30-38

Undang-Undang Dasar NRI Tahun 1945

Undang Nomor 13 Tahun 2003 tentang Ketenagakerjaan

Peraturan Pemerintah Nomor 122 Tahun 2015 tentang Sistem Penyediaan Air Minum

Peraturan Presiden Nomor 70 Tahun 2012 tentang Perubahan Kedua atas Peraturan Presiden Nomor 54 Tahun 2010 tentang Pengadaan Barang/Jasa Pemerintah

Kitab Undang-Undang Hukum (KUH) Perdata 